\title{
Solitary Maxillary Central Incisor along with Mesiodens- Report of a Rare Case with Literature Review
}

\author{
${ }^{1}$ NB Nagaveni, ${ }^{2}$ P Poornima, ${ }^{3}$ Shruti Singh, ${ }^{4}$ Safina Masroor
}

\begin{abstract}
Dental anomalies of tooth number in development of the permanent dentition are quite common than the primary dentition. However, the combined occurrence of hypodontia and hyperdontia is a rare phenomenon, especially in the same dental arch, congenital absence of maxillary central incisor is still the rarest entity. The purpose of this report is to describe a rare case of a solitary maxillary permanent central incisor in association with labially erupted mesiodens.
\end{abstract}

Keywords: Agenesis, Mesiodens, Solitary maxillary central incisor.

How to cite this article: Nagaveni NB, Poornima P, Singh S, Masroor S. Solitary Maxillary Central Incisor along with Mesiodens-Report of a Rare Case with Literature Review. CODS J Dent 2017;9(1):30-35.

\section{Source of support: Nil}

Conflict of interest: None

\section{INTRODUCTION}

Agenesis of one or more teeth in primary or permanent dentition is known as hypodontia, while, hyperdontia is a condition of having extra to the normal complement of teeth. Hypodontia and hyperdontia are two extremes in the development of the dentitions. The occurrence of both these together in the same individual is a form of mixed numeric variation. Although, the existing literature shows exclusively either hyperdontia or hypodontia, however, only a few studies have accounted for the incidence of both the anomalies. ${ }^{1}$ Gibson adopted the term "hypo-hyperdontia" to describe the occurrence in the same individual. ${ }^{2}$ Hypo-hyperdontia may affect primary or permanent dentition and maxilla or mandible. The frequency of hypodontia in permanent dentition ranges from 2 to $10 \%$, and it can also be associated with some other anomalies. ${ }^{3}$ The prevalence of hyperdontia is reported to be between $0.15 \%$ and $3.9 \%$ while the reported

\footnotetext{
${ }^{1}$ Professor, ${ }^{2}$ Professor and HOD, ${ }^{3,4}$ Postgraduate Student

${ }^{1-4}$ Department of Pedodontics and Preventive Dentistry, College of Dental Sciences, Davangere, Karnataka, India

Corresponding Author: NB Nagaveni, Professor, Department of Pedodontics and Preventive Dentistry, College of Dental Sciences, Davangere, Karnataka, India, Phone: +918971695506, e-mail: nagavenianurag@gmail.com
}

prevalence of hypo-hyperdontia is 0.002 to $3.1 \%$ with no gender predilection. ${ }^{4}$

The etiology of hypo-hyperdontia remains masked and it is not evidently documented in the literature. It is inconclusive whether a specific gene or an enzyme defect has an effective role in the development of this condition. Although genetic and environmental factors have been proposed to explain these anomalies in isolation, disturbances in migration, proliferation, and differentiation of neural crest cells and interactions between the epithelial and mesenchymal cells during the initiation of odontogenesis have been suggested to give rise to such a condition. ${ }^{5}$ Excluding third molars, the most affected teeth from hypodontia are maxillary lateral incisors, mandibular and maxillary second premolars in previous studies. Absence of maxillary central incisors, maxillary and mandibular first molars and canines are very rare to be seen. ${ }^{6}$ Supernumerary teeth can be present in both the primary and the permanent dentitions. However, they are almost five times more frequently observed in permanent dentition. ${ }^{7-9}$ Supernumerary teeth mostly occur in the maxilla (80 to $90 \%$ ), and $50 \%$ of them are found in the anterior region. ${ }^{10,11}$ Most commonly seen is the mesiodens which is majorly located in the maxillary central incisor region, having an overall prevalence between $0.15 \%$ and $1.9 \% .^{7-9}$ The presence of mesiodens has the capacity to affect patient esthetics and occlusion by the altering natural eruption path of permanent incisors. The etiology of mesiodens can be attributed to any intrusion injuries to deciduous teeth, genetic predilection, and hyperactivity of the dental lamina. ${ }^{9-12}$ The most common tooth morphology of mesiodens is characterized by a conical crown and short root. Mesiodens having completely formed roots often erupt into the oral cavity. ${ }^{13}$

Agenesis of one of the maxillary central incisor, presenting in the form of solitary maxillary central incisor is very rare. A similar condition is solitary median maxillary central incisor (SMMCI) syndrome, which involves mutations in Sonic hedgehog gene. It involves midline structures of the face, emerges in the midline, occurs in both primary and permanent dentitions. Patients with SMMCI presents, short philtrum, arched upper lip, narrow palate, absent intermaxillary sutures, absent upper labial frenum, and incisive papilla. ${ }^{14}$ 
Early diagnosis of SMMCI is necessary as it might be associated with other syndromes and anomalies. Unlike SMMCI, solitary maxillary central incisor presents a common shape, with distinct mesial and distal thirds of the facial surface, and is located lateral to the midline (i.e., left or right). ${ }^{15}$ It may also not occur in both dentitions.

Additionally, the incisive papilla and upper labial frenum are present. ${ }^{16}$

The purpose of this manuscript is to report a very rare case of a child with only one maxillary permanent central incisor along with the presence of mesiodens at the place of missing counterpart central incisor. Correct diagnosis of SMMCI should be made in a child as if detected early can be referred for genetic counseling.

\section{CASE REPORT}

A 15-year-old girl reported to the Department of Pedodontics and Preventive Dentistry, College of Dental Sciences, Davangere, Karnataka, India with a chief

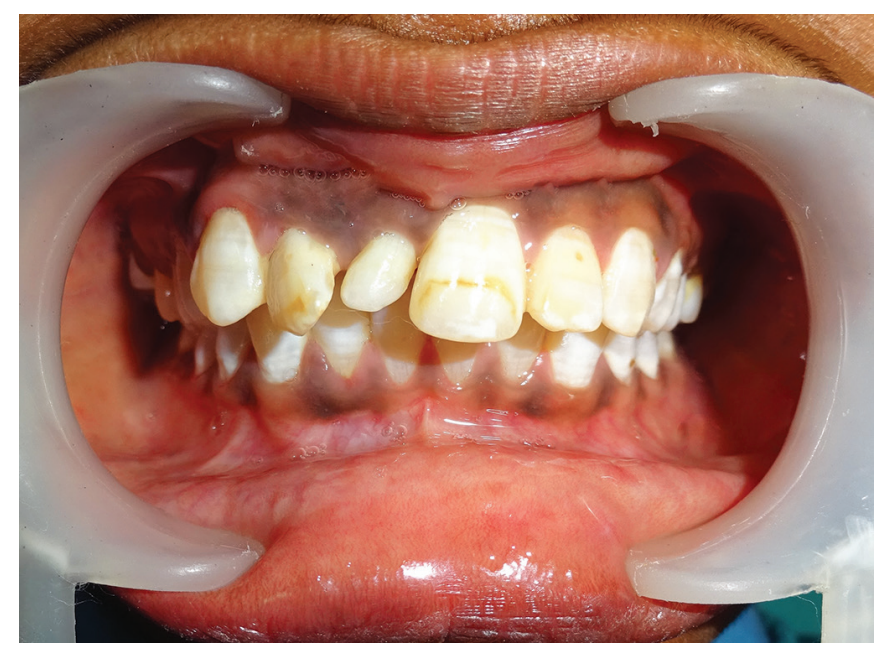

Fig. 1: Preoperative frontal view showing single left central incisor and missing right central incisor

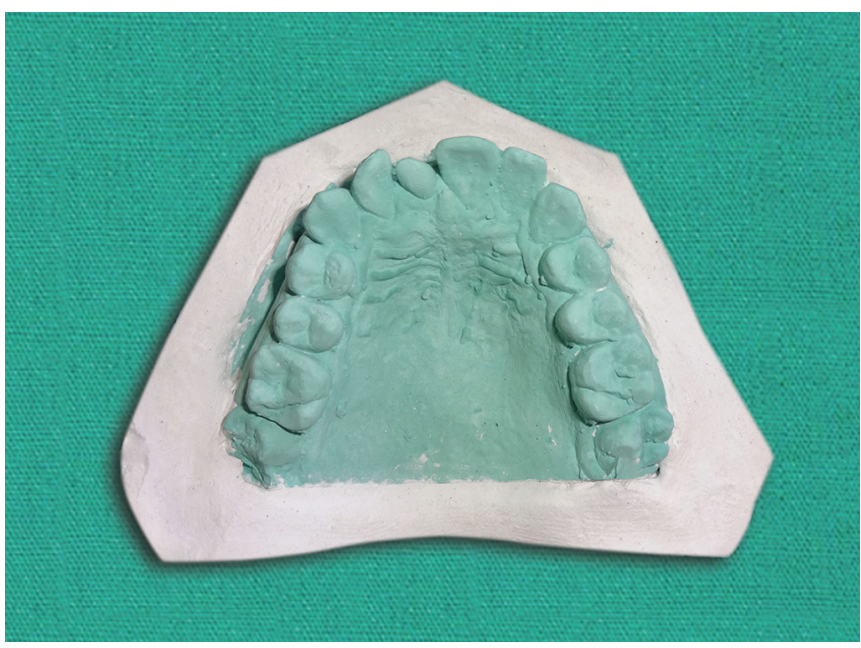

Fig. 3: Maxillary cast depicting conical mesiodens complaint of the presence of a small tooth in upper front tooth region. She was a normal healthy child with noncontributory medical history. The mother gave a history of normal delivery and a child was born to non-consanguineous parents. The family history reveals sibling with no such occurrence. Parents gave no history of trauma and normally erupted primary teeth. Intraoral examination showed the presence of permanent dentition with proclined left maxillary central incisor with mesiodens in place of right maxillary central incisor with right maxillary central incisor clinically missing (Figs 1 to 3 ). Anterior incisor space was reduced due to mesial drift of erupted permanent left central incisor and distopalatally rotated right maxillary lateral incisor. There was the presence of angle's class II molar relation bilaterally and generalized mild fluorosis was noted. An intraoral radiograph was advised which revealed the presence of mesiodens in place of a right maxillary central incisor with congenitally missing permanent right maxillary central incisor (Fig. 4). The radiograph indicated the pres-

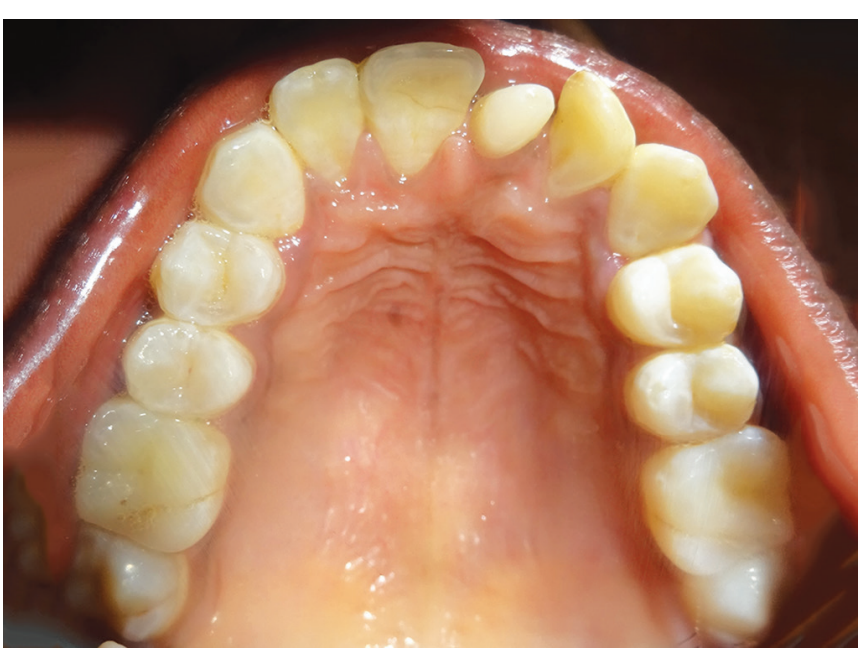

Fig. 2: Preoperative maxillary occlusal view

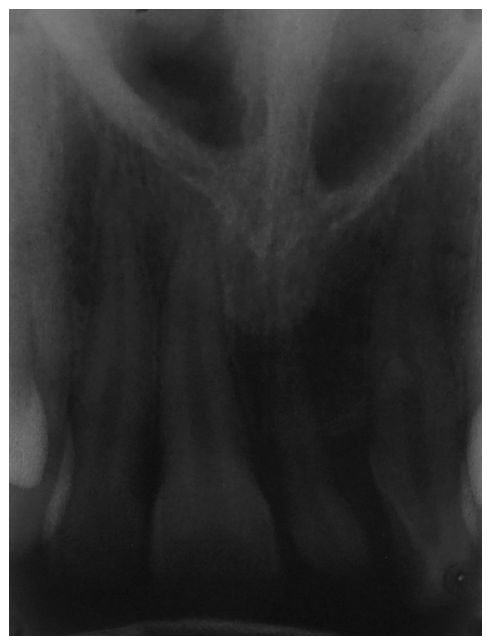

Fig. 4: Intraoral periapical radiograph showing conical shaped mesiodens in place of missing right central incisor 


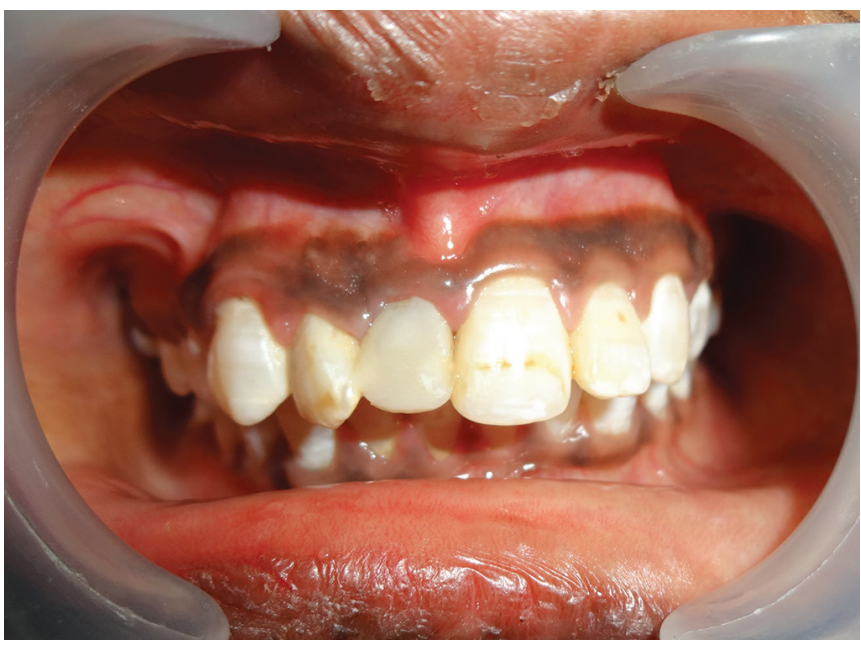

Fig. 5: Postoperative frontal view depicting esthetic composite build up of mesiodens

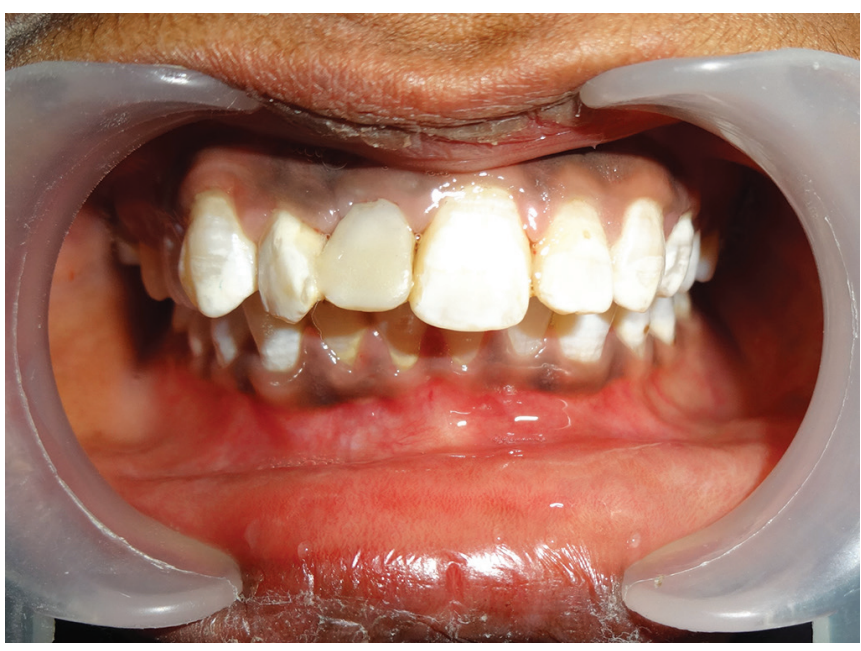

Fig. 7: 18 months follow-up frontal view

ence of well-formed, labially placed mesiodens, with its long axis vertical in the alveolus, with a conical crown and long and straight root. The mesiodens had a flat surface with a mesiodistal width of $5.5 \mathrm{~mm}$. Considering the age of the patient, clinical and radiographic findings, it was decided to carry out aesthetic restoration of mesiodens with anterior composites (Figs 5 and 6). The patient was recalled for follow up after every 6 months. At 18 months follow up satisfactory acceptable esthetics was seen and the patient was happy with the treatment (Fig. 7).

\section{DISCUSSION}

Anterior maxillary teeth are one of the most important features contributing to the aesthetics of an individual. Missing anterior teeth can cause psychological stress in children, during their growing years and can impede their behavioral and personality development.

The present case report revealed solitary maxillary left central incisor in permanent dentition with the presence of labially placed mesiodens in the space of missing right central incisor. This case is unique as it shows the

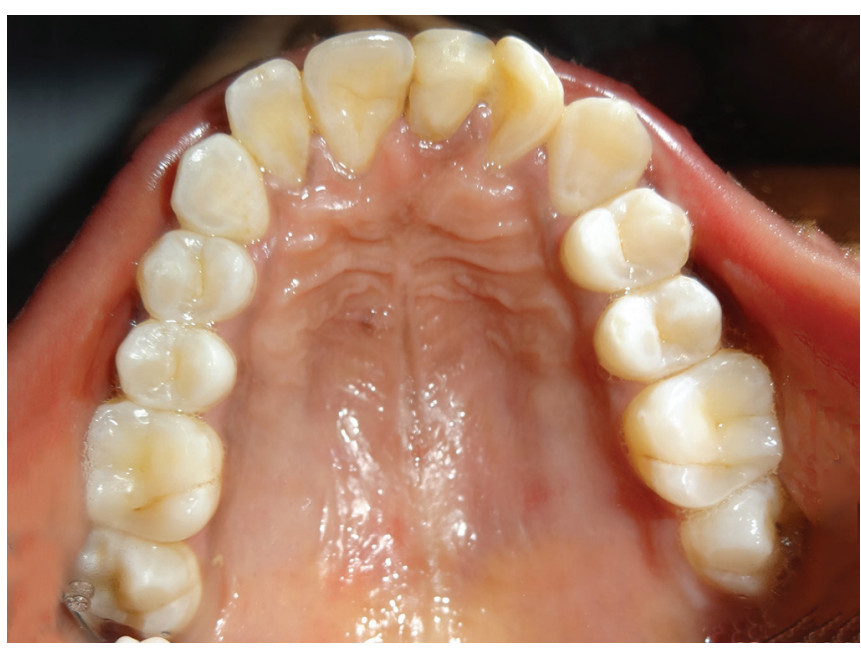

Fig. 6: Postoperative maxillary occlusal view

presence of supernumerary tooth in association with unilateral agenesis of the permanent maxillary central incisor, which is very rare. Etiologies proposed for hypodontia include any failure of tooth bud proliferation from dental lamina due to trauma, infections like rubella, osteomyelitis or use of drugs like thalidomide, genetic factors like mutation of muscle segment homeobox (MSX1) and paired box genes (PAX9), chemotherapy at very young age and presence of syndromes like ectodermal dysplasia and nonsyndromic conditions like cleft lip alveolus with or without cleft palate. Tooth agenesis is probably caused by various independent defective genes either acting alone or coupled with others to produce a specific phenotype. ${ }^{3}$

A similar condition SMMCI syndrome (phenotype) is a unique developmental abnormality, arising from an unknown events occurring between the 35th and 38th days in utero, and involving midline structures of the head including the cranial bones, the maxilla and its associated dentition (specifically the central incisor tooth germs), the nasal airways (choanal atresia, midnasal stenosis or congenital pyriform aperture stenosis), and sometimes the brain (holoprosencephaly), along with other midline structures of the body. ${ }^{17}$ The characteristics of tooth present in this syndrome are: solitary occurring central incisor in the maxilla present precisely in the midline of maxillary alveolus which might have unusual crown form. Hence, the acronym SMMCI syndrome. The circumstances where only one central incisor tooth is present and is not SMMCI includes failure of normally developing incisor to proceed beyond cellular development stage where remaining normal tooth develops to one side of midline, but may erupt in or near the midline; traumatic loss of one incisor; mesiodens of conical form erupting in midline but developing to one or other side of midline in permanent dentition only. ${ }^{17}$ Patients with SMMCI did not present a distinct philtrum, maxillary 
labial frenulum, or incisive papilla. The fact that the tooth was not exactly in the midline, and the presence of the incisive papilla, philtrum, and the maxillary labial frenulum confirmed the diagnosis of agenesis of the right permanent maxillary central incisor. Knowledge of the clinical features of these two entities is crucial because the presence of an SMMCI can be linked to several important systemic manifestations and can be passed on to the patient's offspring. Unfortunately, most dentists treat cases of SMMCI as agenesis. These patients may present undiagnosed malformations and substantial mutations in their genome. Since both conditions occur in the anterior region of the oral cavity leading to poor esthetics, the dentist is often the first professional sought by patients and should, therefore, be able to make the differential diagnosis between an SMMCI and agenesis of the maxillary central incisor. In cases of diagnosis of an SMMCI, the patient should be referred for a thorough medical evaluation, including neurological, cardiac, endocrine, and genetic assessment. ${ }^{18}$ In our case, all the syndromic features were ruled out and diagnosed as nonsyndromic. Table 1 shows the list of cases of a solitary maxillary central incisor in the literature till date. ${ }^{19-57}$

The occurrence of the supernumerary tooth in the maxillary anterior segment is a common entity. Primosch ${ }^{10}$ described two types of mesiodens as supplemental and rudimentary. Supplemental mesiodens resemble normal tooth and are also named as incisiform. Rudimentary mesiodens can be categorized into three types based on their morphology as conical, tuberculate and molariform. Conical mesiodens are generally solitary, have completely formed roots and are commonly seen palatal to maxillary central incisors. ${ }^{4}$ The patient described in the current report too exhibited conically shaped mesiodens with completely formed root but was seen in a labial position which is a deviation from its palatal occurrence. About $90 \%$ of the mesiodens reported are situated palatal to the associated permanent tooth. Very rarely a mesiodens is encountered on the labial aspect of the permanent tooth and in 28 to $63 \%$ of cases, mesiodens is noted to cause an ectopic eruption, displacement or rotation of a permanent central incisor. ${ }^{17}$ In a situation such as this, a mesiodens in a favorable position could be considered to replace a permanent missing tooth. Most literature available describes the need for early recognition of the mesiodens and its extraction, to avoid any displacement, developmental anomalies or delayed eruption of the associated permanent tooth. Early extraction of a supernumerary or mesiodens in the mixed dentition is recommended, to allow for optimal yet minimal treatment for the permanent successor. However, in the
Table 1: Summary of reported solitary maxillary central Incisor in the literature ${ }^{19-57}$

\begin{tabular}{|c|c|c|c|}
\hline $\begin{array}{l}\text { Sl. } \\
\text { No. }\end{array}$ & Author/year & Syndromic & $\begin{array}{l}\text { Non } \\
\text { syndromic }\end{array}$ \\
\hline 1. & Rappaport EB, 1977 & & Yes \\
\hline 2. & Wesley RK, 1978 & & Yes \\
\hline 3. & Boudailliez B, 1983 & Yes & \\
\hline 4. & Marechaux SC, 1986 & & Yes \\
\hline 5. & Liberfarb RM, 1987 & & Yes \\
\hline 6. & Suss J, 1990 & Yes & \\
\hline 7. & Miura M, 1993 & & Yes \\
\hline 8. & Kocsis SG, 1994 & Yes & \\
\hline 9. & Roger K. Hall, 1997 & Yes & \\
\hline 10. & M. Harrison, 1997 & Yes & \\
\hline 11. & F. S. Lo, 1998 & Yes & \\
\hline 12. & Triona McNamara, 1999 & Yes & \\
\hline 13. & Parentin F, 2003 & Yes & \\
\hline 14. & Tubbs RS, 2004 & Yes & \\
\hline 15. & Hehr U, 2004 & Yes & \\
\hline 16. & Garavelli L, 2004 & Yes & \\
\hline 17. & Yang HC, 2005 & Yes & \\
\hline 18. & Talmant J, 2006 & & Yes \\
\hline 19. & S. Y. Cho, 2006 & & Yes \\
\hline 20. & Garcia de Paula e Silva FW, 2007 & Yes & \\
\hline 21. & Jinda lertsirivorakul, 2008 & Yes & \\
\hline 22. & Tabatabaie F, 2008 & & Yes \\
\hline 23. & Michele Bolan, 2009 & Yes & \\
\hline 24. & Elizabete da Silva Viana, 2010 & Yes & \\
\hline 25. & Kate blackmore, 2010 & Yes & \\
\hline 26. & Jesus Gimento hernandaz , 2010 & Yes & \\
\hline 27. & Catania P, 2010 & Yes & \\
\hline 28. & Michele Bolan, 2010 & & Yes \\
\hline 29. & Ashok Utreja, 2011 & Yes & \\
\hline 30. & Gurunathan D, 2011 & & Yes \\
\hline 31. & F. S. Van dijk, 2011 & Yes & \\
\hline 32. & Da silva viana, 2011 & & Yes \\
\hline 33. & Nanni L, 2011 & Yes & \\
\hline 34. & Kjaer, 2012 & & Yes \\
\hline 35. & Ahmet Ercan Sekerci, 2012 & Yes & \\
\hline & G. Shilpa, 2012 & & Yes \\
\hline 37. & N. N. Lygidakis, 2013 & Yes & \\
\hline 38. & Delforge A, 2013 & & Yes \\
\hline 39. & Lutz Günther, 2014 & Yes & \\
\hline 40. & $\begin{array}{l}\text { Fabricio Kitazono de Carvalho, } \\
2014\end{array}$ & & Yes \\
\hline 41. & Holla G, 2014 & Yes & \\
\hline 42. & Deepak Chandrasekaran, 2015 & & Yes \\
\hline & Simon Poelmans, 2015 & Yes & \\
\hline & Sara Yang, 2016 & Yes & \\
\hline 45. & Ilhan O, 2018 & Yes & \\
\hline
\end{tabular}

event of a malformed, impacted permanent successor, all efforts should be taken to analyze and identify the path of eruption and location of the impacted mesiodens relative to the adjacent structures, and development of an appropriate treatment plan evolved to preserve and guide it to the desired position. Once a mesiodens have been diagnosed, the clinician must focus on early treatment to prevent further sequelae. ${ }^{18}$ This paper is unique 
in that a very rarely seen labially placed mesiodens was detected in a favorable position and was used to replace a missing central incisor providing the patient with satisfactory esthetics.

\section{CONCLUSION}

The occurrence of both hypodontia (agenesis of unilateral permanent maxillary central incisors) and supernumerary tooth in the maxillary dental arch is an uncommon and extremely rare dental phenomenon. A careful history, clinical examination with detailed radiographic evaluation enhances the diagnosis ultimately helping to provide an appropriate treatment plan.

\section{REFERENCES}

1. Anthonappa RP, Lee CK, Yiu CK, King NM. Hypohyperdontia: Literature review and report of seven cases. Oral Surg Oral Med Oral Pathol Oral Radiol Endod. 2008;106:24-30.

2. Gibson AC. Concomitant hypo-hyperodontia. Br J Orthod 1979;6:101-105.

3. Thanakapann P, Joseph TI, Chundru NSV, Kumar NRS. Congenitally missing maxillary central incisor in incisor premolar hypodontia: A rare case report. J Indian Aca Oral Med Radiol 2013;25(3):248-250.

4. Nagaveni NB, Bajaj M, Muthusamy K, Poornima P, Pai SM, Subba Reddy VV. Concomitant mandibular hypo-hyperdontia: Report of two rarest cases with literature review. Int J Contemp Dent Med Rev; 2014;6:1-6.

5. Ranta R. Numeric anomalies of teeth in concomitant hypodontiaand hyperdontia. J Craniofac Genet DevBiol 1988;8:245-251.

6. Peker I, Kaya E, Darendeliler-Yaman S. Clinical and radiographical evaluation of non-syndromic hypodontia and hyperdontia in permanent dentition. Med Oral Patol Oral Cir Bucal. 2009 Aug 1;14(8):393-397.

7. Sykaras SN. Mesiodens in primary and permanent dentitions. Report of a case. Oral surgery, oral medicine, and oral pathology. 1975;39(6):870-874.

8. Sykaras SN. Totally inverted mesiodens. Oral surg, Oral Med, and Oral Pathol.1975; 39(5):834.

9. Sedano HO, Gorlin RJ. Familial occurrence of mesiodens. Oral Surg, Oral Med, and Oral Pathol. 1969;27(3):360-361.

10. Primosch RE. Anterior supernumerary teeth-assessment and surgical intervention in children. Pediatric Dentistry. 1981;3(2): 204-215.

11. Hattab FN, Yassin OM, Rawashdeh MA. Supernumerary teeth: report of three cases and review of the literature. ASDC J Dent Child. 1994;61(5-6):382-393.

12. Diab M, Badrawy HE. Intrusion injuries of primary incisors. Part III: Effects on the permanent successors. Quintessence Int 2000;31(6):377-384.

13. Sheikh Z, Manzoor A, Amir N. Mesiodens - A common supernumerary tooth: Report of management of a case with two mesiodens. IDJSR 2014;2(3):41-46.

14. Carvalho FK, Arid J, Rossi A, Paula-Silva FW, Nelson-Filho P. Solitary Median Maxillary Central Incisor Versus Agenesis of the Maxillary Central Incisor. J Dent Child (Chic). 2016;83(1):29-32.
15. Tichler HM, Abraham JE. Management of a con-enitally missing maxillary central incisor: a case study. NY State Dent J 2007;73(2):20-22.

16. Antal M. Replacing Congenitally missing central incisor: a case report with a special method to achieve the optimal emergence profile. Dent Case Report Surg Curr Res 2013; S11:1-4.

17. Hall RK. Solitary median maxillary central incisor (SMMCI) syndrome. Orphanet J Rare Dis. 2006 Apr 9;1:12.

18. Ephraim R, Dilna NC, Sreedevi S, Shubha M. A labially positioned mesiodens and its repositioning as a missing central incisor. J Int Oral Health 2014;6(5):114-117.

19. Pseiner BC. Premolar transplantation in a patient with solitary median maxillary central incisor syndrome. Am J Orthod Dentofacial Orthop 2014;146:786-794.

20. Bolan M, Derech CA, Correa M, Ribeiro GLU, Almeida ICS. Palatal expansion in a patient with solitary median maxillary central incisor syndrome. Am J Orthod Dentofacial Orthop 2010;138:493-497.

21. Hall RK, Bankier A, Aldred MJ, Kan K, Lucas JO. Solitary median maxillary central incisor, short stature, choanal atresia/midnasal stenosis (SMMCI) syndrome. Oral Surg Oral Med Oral Pathol Oral Radiol Endod 1997;84:651-662.

22. Gunther L, Sari-Rieger A, Jablonka K, Rustemeyer J. Clinical course and implications of congenital nasal pyriform stenosis and solitary median maxillary central incisor in a newborn: a case report. J Med Case Reports 2014;8:215.

23. Carvalho FK, Arid J, Rossi AD, Paula-Silva FWG, Nelson-Filho P. Solitary Median Maxillary Central Incisor Versus Agenesis of the Maxillary Central Incisor. J Dent Child 2016;83(1):29-32.

24. DiBiase AT, Cobourne MT. Beware the solitary maxillary median central Incisor. JO 2008;35:6-19.

25. Cho SY, Drummond BK. Solitary median maxillary central incisor and normal stature : a report of three cases. Int J Paed Dent 2006;16:128-134.

26. Utreja A, Zahid SN, Gupta R. Solitary median maxillary central incisor in association with hemifacial microsomia: a rare case report and review of literature. Contemp Clin Dent; Oct-Dec 2011;2(4).

27. Shilpa G, Nuvvula S, Gokhale N, Yamini V. Concomitant solitary median maxillary central incisor and fused right mandibular incisor in primary dentition. Contemp Clin Dent; Sept 2012;3(2).

28. Harrison M, Calvert L, Longhurs P. Solitary maxillary central incisor as a new finding in charge association: a report of two cases. Inter J Paed Dent 1997;7:185-189.

29. Gurunathan D, Tandon S, Krishnan R, Kalra M. Solitary odontodysplasia: A rare entity. J Indian Soc Pedod Prev Dent, Dec 2011;29(2).

30. Chandrasekaran D, Yezdani A, Tajir F, Saravanan B, Rajasekar L. Solitary median maxillary central incisor: A case report of a rare dental anomaly. J Pharm Bioall Sci 2015;7:307-308.

31. lacLertsirivorakul J, Hall RK. Solitary median maxillary central incisor syndrome occurring together with oromandibular-limb hypogenesis syndrome type 1: a case report of this previously unreported combination of syndromes. Inter J Paed Dent 2008;18:306-311.

32. Yang S, Orta P, Elizabeth M, Renk MD, Inman JC. Congenital nasal pyriform aperture stenosis in association with solitary median maxillary central incisor : unique radiologic features. Radiology Case Reports 2016:11(3)178-181. 
33. McNamara T, Field D, McNamara T. A solitary maxillary central incisor treated orthodontically: a case report. Special Care in Dent 1999;19(3):135-8.

34. Poelmans S, Kawamoto T, Cristofoli F, Politis C, Vermeesch J, Bailleul-Forestier I, et al. Genotypic and phenotypic variation in six patients with solitary median maxillary central incisor syndrome. Am J Med Genet Part A 2015;167:2451-2458.

35. Viana EDS, Kramer PF, Closs LQ, Scalco G. Solitary Median Maxillary Central Incisor Syndrome and Holoprosencephaly: A Case Report. Pediatr Dent 2010;32:424-427.

36. Bolan M, Derech CA, Ribeiro GLU, Pereira ET, Almeida ICS. Solitary Median Maxillary Central Incisor. J Dent Child 2009;76:82-86

37. Sekerci AE, Ucar FI, Gumus H, Aydınbelge M, Sisman Y. Solitary Median Maxillary Central Incisor: A Report of 2 Cases. Pediatr Dent 2012;34:150-155.

38. Nanni L, Ming JE, Du Y, Hall RK, Aldred M, Bankier A, et al. SHH mutation is associated with solitary median maxillary central incisor: a study of 13 patients and review of the literature. Am J Med Genet. 2001 Jul 22;102(1):1-10.

39. Yassin OM, El-Tal YM. Solitary maxillary central incisor in the midline associated with systemic disorders. Oral Surg Oral Med Oral Pathol Oral Radiol Endod. 1998 May;85(5):548-551.

40. Tabatabaie F, Sonnesen L, Kjaer I. The neurocranial and craniofacial morphology in children with solitary median maxillary central incisor (SMMCI). Orthod Craniofac Res. 2008 May;11(2):96104.

41. Yang HC, Shyur SD, Huang LH, Chang YC, Wen DC, Liang $\mathrm{PH}$, Lin MT. DiGeorge syndrome associated with solitary median maxillary central incisor. Asian Pac J Allergy Immunol. 2005 Jun-Sep;23(2-3):159-163.

42. Wesley RK, Hoffman WH, Perrin J, Delaney JR Jr. Solitary maxillary central incisor and normal stature. Oral Surg Oral Med Oral Pathol. 1978 Dec;46(6):837-842.

43. Garavelli L, Zanacca C, Caselli G, Banchini G, Dubourg C, David V, Odent S, Gurrieri F, Neri G. Solitary median maxillary central incisor syndrome: clinical case with a novel mutation of sonic hedgehog. Am J Med Genet A. 2004 May 15;127(1):93-95.

44. Rappaport EB, Ulstrom RA, Gorlin RJ, Lucky AW, Colle E, Miser J. Solitary maxillary central incisor and short stature. J Pediatr. 1977 Dec;91(6):924-928.

45. Garcia de Paula e Silva FW, de Carvalho FK, Diaz-Serrano KV, de Freitas AC, Borsatto MC, de Queiroz AM. Soli- tary median maxillary central incisor in association with Goldenhar's syndrome: a case report. Spec Care Dentist. 2007 May-Jun;27(3):105-107.

46. Suss J, Pfeiffer RA, Zschiesche S, Konig R. A solitary central maxillary incisor and holoprosencephaly in sibling. Dtsch Zahnarztl Z. 1990 Dec;45(12):785-788.

47. Liberfarb RM, Abdo OP, Pruett RC. Ocular coloboma associated with a solitary maxillary central incisor and growth failure: manifestations of holoprosencephaly. Ann Ophthalmol. 1987 Jun;19(6):226-227.

48. Marechaux SC. The single maxillary central primary incisor: report of case. ASDC J Dent Child. 1986 Mar-Apr;53(2):124-126.

49. Parentin F, Perissutti P. Solitary median maxillary central incisor, Duane retraction syndrome, growth hormone deficiency and duplicated thumb phalanx: a case report. Clin Dysmorphol. 2003 Apr;12(2):141-142.

50. Kocsis SG. A single central maxillary incisor in the midline as a mild form of holoprosencephaly. Fogorv Sz. 1994 Mar;87(3): 63-70.

51. Boudailliez B, Morichon-Delvallez N, Goldfarb A, Pautard JC, Lenaerts C, Piussan C. Solitary upper incisor, hypopituitarism and monosomy 18p chromosome aberration. J Genet Hum. 1983 Sep;31(3):239-242.

52. Miura M, Kato N, Kojima H, Oguchi H. Triple-X syndrome accompanied by single maxillary central incisor: case report. Pediatr Dent. 1993 May-Jun;15(3):214-217.

53. Talmant J, Deniaud J. The role of the maxillary incisors in the development of the base of the nose. Applications in dentofacial orthopedics. Orthod Fr. 2006 Mar;77(1):19-62.

54. Delforge A, Raoul G, Fayoux P, Ferri J. Congenital piriform aperture stenosis and odontogenic disorders. Rev Stomatol Chir Maxillofac Chir Orale. 2013 Apr;114(2):59-62.

55. Ilhan O, Pekcevik Y, Akbay S, Ozdemir SA, Memur S, Kanar B, et al. Solitary median maxillary central incisor, holoprosencephaly and congenital nasal pyriform aperture stenosis in a premature infant: case report. Arch Argent Pediatr. 2018 Feb 1;116(1):130-134.

56. Tubbs RS, Oakes WJ. Lumbosacral agenesis and anteroposterior split cord malformation in a patient with single centralmaxillary incisor: case report and review of the literature. J Child Neurol. 2004 Jul;19(7):544-547.

57. Hehr U, Gross C, Diebold U, Wahl D, Beudt U, Heidemann $\mathrm{P}$, et al. Wide phenotypic variability in families with holoprosencephaly and a sonic hedgehog mutation. Eur J Pediatr. 2004 Jul;163(7):347-352. 